\title{
Macron Struggles to Reunite a Divided Country
}

French President Emmanuel Macron faces severe difficulties putting his ambitious plans for France's 'transformation' into practice. For months, the 'yellow vest movement' (mouvement des gilet jaune) has dominated the public debate. It has grown from a spontaneous protest against rising fuel taxes to a broad movement with heterogeneous claims and diverse protestors. Despite losing steam, a more radical core continues to vigorously challenge the French government. Right- and leftwing extremist parties are both trying to canalise the protest into their respective ideological camp, but the protest still seems to go beyond any organisational logic. The lasting vehemence of the movement is posing a serious threat to Macron's presidency.

Almost two years after his election, Macron finds himself at a crucial moment for three reasons: First, the movement has disrupted the political agenda of profound social and economic reforms that he has pursued since the beginning of his campaign. Second, traditional responses to social unrest are less effective when the protest movement is organised outside of a civil society group. Non-extreme opposition parties are too weak to serve as a more moderate mouthpiece for the protestors and labour unions don't have the prerogative to address issues of social justice anymore. As the protest's roots reach far deeper than a mere opposition to specific reforms, there is no easy way out of the current crisis. Macron is in a risky position and the outcome remains uncertain. Finally, the crisis comes only a few months ahead of European elections and threatens to overthrow Macron's robust stance for a new European vision. With his success in pushing forward EU reforms hinging on the successful implementation of reforms inside France and viceversa, Macron now finds himself blocked on both levels. Whereas his opponents can build their electoral campaigns around refuting Macron's politics in general, Macron and his movement La République en marche (LREM) will struggle to put European issues in the centre of their campaign. This increases the risk of rightwing-populist parties having landslide victories in the European elections.

Since the beginning of Macron's presidential campaign, he put social and economic reforms at the centre of his manifesto; effectively using the notion of 'transforming' rather than 'reforming' to mark a rupture with his predecessors. His approach follows the idea of 'flexicurity': economic liberalisation of the labour market and social security at the same time. By making the rigid French labour market more flexible, he intends to boost employment and economic performance, thereby reducing the state's deficit in combination with budget cuts. But putting liberalisation into practice too quickly without social secutity measures as a counterbalance resulted in growing public discontent that culminated in the protests to rising fuel taxes.

Once elected, Macron made the mistake of legitimising his reform mandate based on the fact that he believed reforming was what the French people wanted from him. This allowed him and the government to push through extensive reforms of the labour law, the state-owned railway company SNCF or vocational training at a fast pace. His initial reaction to the resistance to his reform was to ignore it - rather than attempting to rally a steady stream of support for his policies. The moniker 'president of the rich' stuck after he abolished the property tax as one of his first initiatives: While the move made sense from an economic standpoint as it provided incentives for private investments, the symbolism of this gesture greatly damaged his reputation. This tax stood for redistribution more than any other. It is not surprising that one of the yellow vest's core demands is the restoration of this tax. 
During the first year of reforms, many measures had an immediate positive effect on the wealthy whereas low and middle-range incomes were taxed at comparatively higher rates or had to wait for the reforms to take hold. Macron's economic and fiscal policy hence aggravated social injustice instead of diminishing them at the beginning of the presidency. The concessions following the ongoing protests in December were considerable (e.g. a state-funded contribution to increase minimum wage), but were too late to have their intended effect of calming the uprisings. By that time, anti-elitist narratives were flourishing and Macron was being portrayed as an enemy of the people together with a call for system change. He is now heavily reliant on the immediate success of his recent concessions to increase social expenditures including subsidies for minimum wage and the abolition of taxes on overtime pay and a controversial tax on pensions.

The protests are not only about discontent with government reforms, they are also opposed to Macron himself and what they feel he represents. Macron contributed to this image by modeling the presidential role on the Fifth Republic, which is defined by centralised power that is also strongly personalised. What many see as Macron's vertical governing style leads him to be more distant, more aloof from his constituency. Additionally, he undermined the significance of political parties by declaring them and their left-right orientation 'outdated' after the success of his LREM movement. At present, the Socialists are marginalised and the Conservatives are adrift somewhere between the LREM and the far right. The only viable opposition comes from the leftist La France insoumise (LFI) and far right Rassemblement national $(\mathrm{RN})$ - both challenging the core of France's institutions. Labour unions, formerly the watchdogs of French reform, are weakened by their fragmentation and can hardly find common ground. The government tried to benefit from this weakness by limiting social dialogue ahead of the reforms to toothless consultations.

Macron based his campaign and focus of his movement on personal encounters and dialogue. He expressed his determination to reduce a democratic deficit and to get all citizens involved in politics. But his actions do not mirror his words. The 'national debates' announced in a 'letter to the nation' and launched in mid-January have two goals: First, they hope to build on the successful formula of the campaign. Second, they intend to reduce the current tension and help Macron to stabilise his governance. For both of these objectives of the national debates to be met, Macron must project willingness to adjust his reform agenda - contrary to previous signals that he was not open to change.

If Macron fails to reunite a majority behind his project, the consequences would reach far beyond France. Mistrust in and rejection of established parties and politics were already a driving force during past French presidential elections and may be even stronger in the upcoming European elections. Macron's ambitions to repeat his election success on the European level by building an 'progressive' alliance and to establish himself as the future kingmaker of either the European conservatives or socialists seem unrealistic now. On the one hand, he must credibly revise his narrative of a cleavage between 'nationalists' and 'progressives' to one of a social Europe - a demand also expressed by the gilets jaune. On the other hand, it will be more difficult for him to find allies with such civil unrest at home as other European parties have not yet been weakened like the traditional parties in France. Macron's impassioned support of European integration among pro-Europeans did not translate into a real political current nor did it alter Eurosceptic or nationalist attitudes - a reminder that the first beneficiaries of flawed policies are nationalist and extremist movements.

Julie Hamann, German Council on Foreign Relations, Berlin, Germany. 